\title{
Monitoring slope creep motion using multi-temporal interferometry synthetic aperture radar in Semarang, Indonesia
} \author{
Zulfikar Ardiansyah Fajria ${ }^{\mathrm{a}}$ Muhammad Taqy ${ }^{\mathrm{a}}$ \\ ${ }^{a}$ Geography Department, Universitas Negeri Semarang, Indonesia [+62 85293410740] \\ ${ }^{\mathrm{b}}$ Puslitbang Tekmira, Ministry of Energy and Mineral Resources, Bandung, Indonesia \\ ${ }^{\mathrm{c}}$ Graduate School of Environmental Science, Hokkaido University, Japan
}

Jamhur $^{\mathrm{a}}$, Vina Nurul Husna ${ }^{\mathrm{a}}$, Willy Hermawan ${ }^{\mathrm{b}}$, Deha Agus Umarhadic, Ratna Jayantia ${ }^{\mathrm{a}}$, Salsabila Faizah Kamila ${ }^{\mathrm{a}}$,

\section{Article Info:}

Received: 22 - 09 - 2021

Accepted: 30 - $11-2021$

Keywords:

InSAR, Semarang City, slope creep

Corresponding Author:

Vina Nurul Husna

Geography Department,

Universitas Negeri Semarang,

Indonesia;

Tel. +6285293410740

Email:

vinanurulhusna@mail.unnes.ac.id

\begin{abstract}
Landslide is one type of slope movement, which includes creep. Although the creep movement does not impact the risk of loss of life, this creep movement takes place constantly and is invisible, affecting economic losses. In this study, a time-series monitoring was carried out from 2018 to 2020 to see the movement of the slopes in the study area using the Multi-Temporal Interferometry Synthetic Aperture Radar (MTInSAR). A time series method from Sentinel 1A/B data, which includes Trangkil Sejahtera Housing (PTS), Soegijapranata Catholic University (UNIKA), and 17 August 1945 University (UNTAG) in Semarang City, Indonesia. The data processing results indicate that there are slope movement in the target location, namely Trangkil Sejahtera and Selorejo Housing (southwest of UNIKA). Based on BPBD 2021 data, landslides occurred in the Trangkil Baru Housing Center (to the north of PTS) and the Garang River landslide channel west of Selorejo. This shows a link between crawling in 2018-2020 and landslides in 2021. Although satellite data has some drawbacks, the results can be taken into consideration in building an early warning system and reducing losses due to landslides.
\end{abstract}

How to cite (CSE Style $8^{\text {th }}$ Edition):

Jamhur, Husna VN, Hermawan W, Umarhadi DA, Jayanti R, Kamila SF, Fajri ZA, Taqy M. 2021. Monitoring slope creep motion using multi-temporal interferometry synthetic aperture radar in Semarang, Indonesia. JPSL 11(4): 524-531. http://dx.doi.org/10.29244/jpsl.11.4.524-531.

\section{INTRODUCTION}

Indonesia is a tropical country with high rainfall every year. Heavy rainfall is one of the triggers for landslides. The phenomenon of landslides often occurs in Indonesia, including the city of Semarang. Important parameters in the analysis of landslide events are geological conditions, topography, land use, rainfall, water and drainage, and the influence of human activities (Naryanto et al., 2019). Urban areas are characterized by intensive land changes without the potential for disasters such as landslides (Ramadhan et al., 2016). According to data from the Regional Disaster Management Agency (BPBD) of Semarang City in 2016-2020, there was an increase in landslide disasters. In 2020, there were around 124 landslide occurrence points in the Semarang City area. Landslide or soil creep is a general term used for high-risk ground motion on unstable slopes. Landslides and creeps include slope movement, but the speed is different. Creeping is a movement that is not visible, but when it reaches the final phase, it can be marked by the presence of cracks (creep failure) on paved roads, split walls or floors in houses or buildings, or curved trees. Damage to roads and buildings due to crawling in certain areas can take place every year, this results in economic losses to the affected community 
due to the need for building renovations that are not only once but even continuous. Landslide events cannot be predicted directly in landslide-prone areas, so there is a need for research on the development of early warning systems, which have been continuously being developed, one of which is through slow deformation monitoring using the PS-InSAR method (Colesanti et al., 2003; Hilley et al., 2004; Gorazd et al., 2012; Meisina et al., 2013; Virk et al., 2018; Mantovani et al., 2019; Aslan et al., 2020).

SAR satellites have sensors that can be used in monitoring surface deformation. Still, there are drawbacks, especially the inability to detect deformations oriented perpendicular to the Line of Sight (LOS) from the satellite sensors (Mazzanti et al., 2012). It is impossible to determine the deformation's actual direction in realtime horizontally so that it is only possible to observe vertical shifts (Samiei-Esfahany et al., 2009). In the case of time series creep observations, the SAR satellite sensor is sensitive in detecting the presence of continuous, slow, and invisible surface movements in relatively in the same direction or opposite to the LOS.

Scrap or Creep failure around areas affected by landslides (Trangkil Baru Housing and Selorejo Housing) are evidence of ground movement. In the research area, these structures are visible on asphalt roads, paving blocks, and buildings in PTS, Selorejo-Tinjomoyo, UNTAG, and UNIKA. This study aimed to monitor the presence of termites in the period 2018 to 2020 and analyze the relationship between termites before the landslide occurred. The occurrence of landslides based on secondary data sentinel satellite $1 \mathrm{~A} / 1 \mathrm{~B}$ time series using the PS-InSAR method, Scarp/creep move data failure in the field to determine and validate the direction of past soil movements, and data on landslide events in 2021.

\section{METHODS}

\section{Location and Research Period}

The research was located in the Garang Watershed, including Trangkil, Selorejo, UNIKA, and UNTAG, areas prone to landslides. There are structural hills caused by slope movement. This research was carried out from June to September 2021 with the division of several research stages.

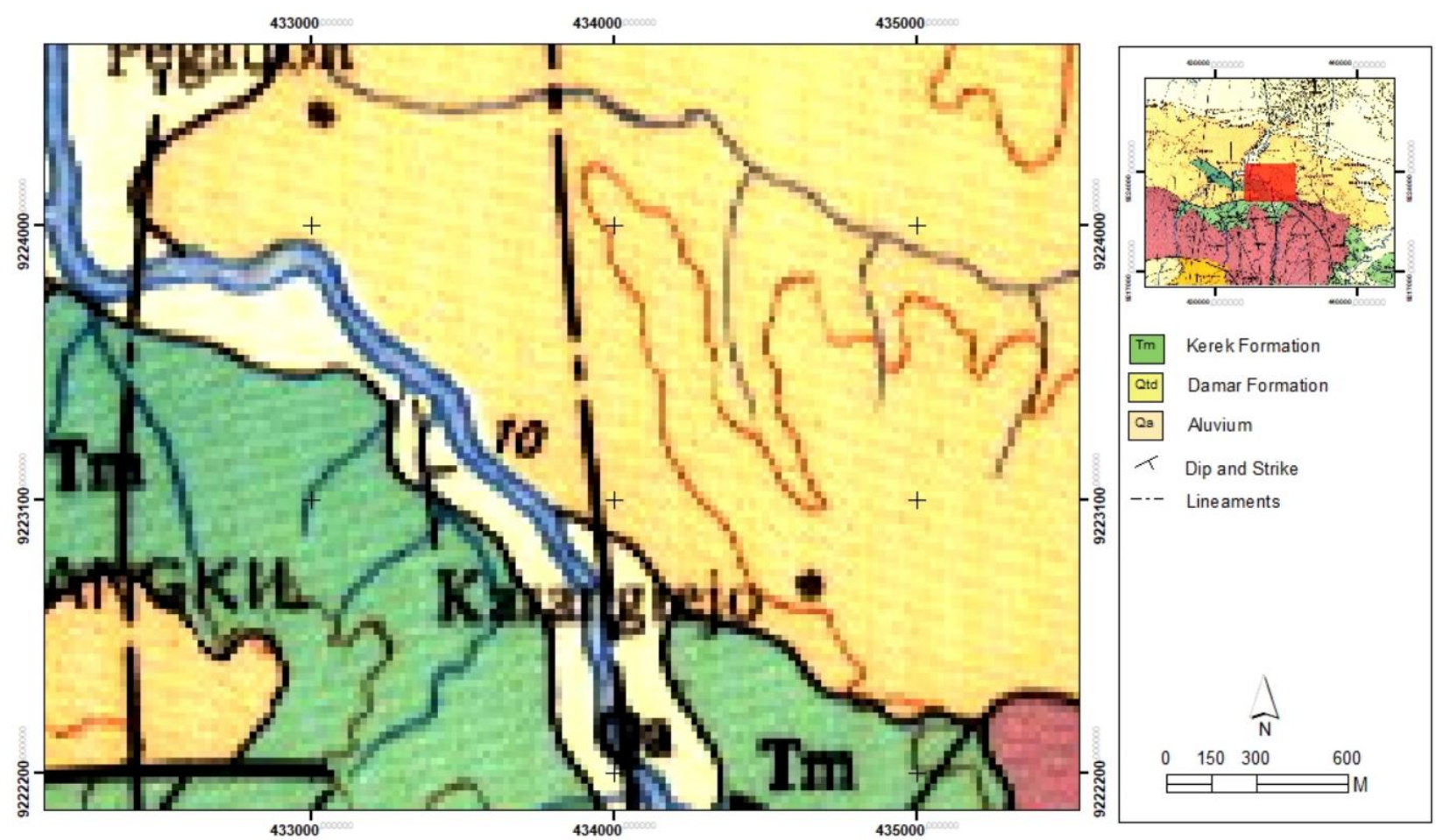

Figure 1 Geological map of the research area (Modification from Thaden et al., 1975) 
Based on the geological map (Figure 1) Trangkil Sejahtera Housing is located above the Kerek Formation which has dip direction of about $50 \mathrm{SW}$, while Selorejo, UNTAG, and UNIKA are located above the Damar Formation which is assumed to have the same dip as the Dam area, which is 15 NE. The Kerek Formation in the research area is a volcanic breccia unit, while the Damar Formation has a breccia unit exposed in Jatibarang Village, Ngaliyan District, and a conglomerate unit that exposed in Meteseh Village, Tembalang District (Paramita et al., 2021).

\section{Data}

The data used in this research, such as Single Look Complex Sentinel 1A/1B satellite data downloaded from https://search.asf.alaska.edu/ as many as 91 ascending images recorded from January 2018 to December 2020, and the recording on June 20, 2019 is used as the master images. For the precise orbit file Sentinel-1 is downloaded from http://step.esa.int/auxdata/orbits/Sentinel-1/. Field data in the form of data collection from Scrap /creep failure and landslide occurrence data in the research area and documentation in the form of scarp and landslide photos.

\section{Data Processing}

The data was processed using the Persistent Scatterers Interferometry Synthetic Aperture Radar method, abbreviated as PS-InSAR, which refers to Ferretti et al., 2001. The processing result is shown as a displacement time series, where the LOS (Line of Sight velocity) velocity of each PS (Persistent Scatterers) displacement series shows surface deformation.

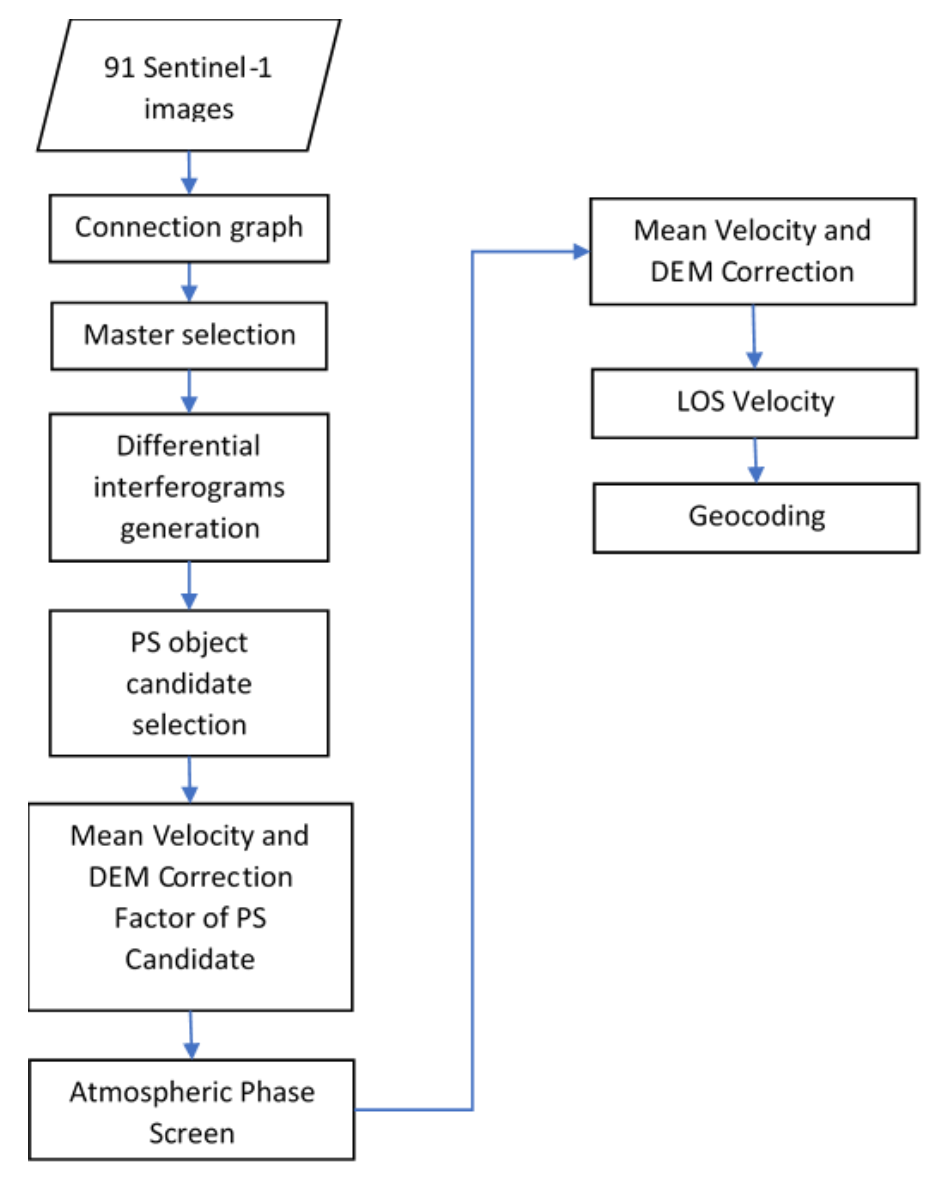

Figure 2 Flowchart of secondary data processing using sentinel 1A/1B 


\section{RESULT AND DISCUSSION}

Sentinel 1 satellite imagery has very few descending recordings in the Semarang area, so the image used is an ascending Sentinel 1A image. A total of 91 were used in PS-InSAR processing. The master image used is the result of recording on 20 June 2019 where the highest perpendicular baseline is $112994 \mathrm{~m}$ for the master image used and the coherence threshold used is 0.75 and the area with coherence below 0.75 cannot be estimated.

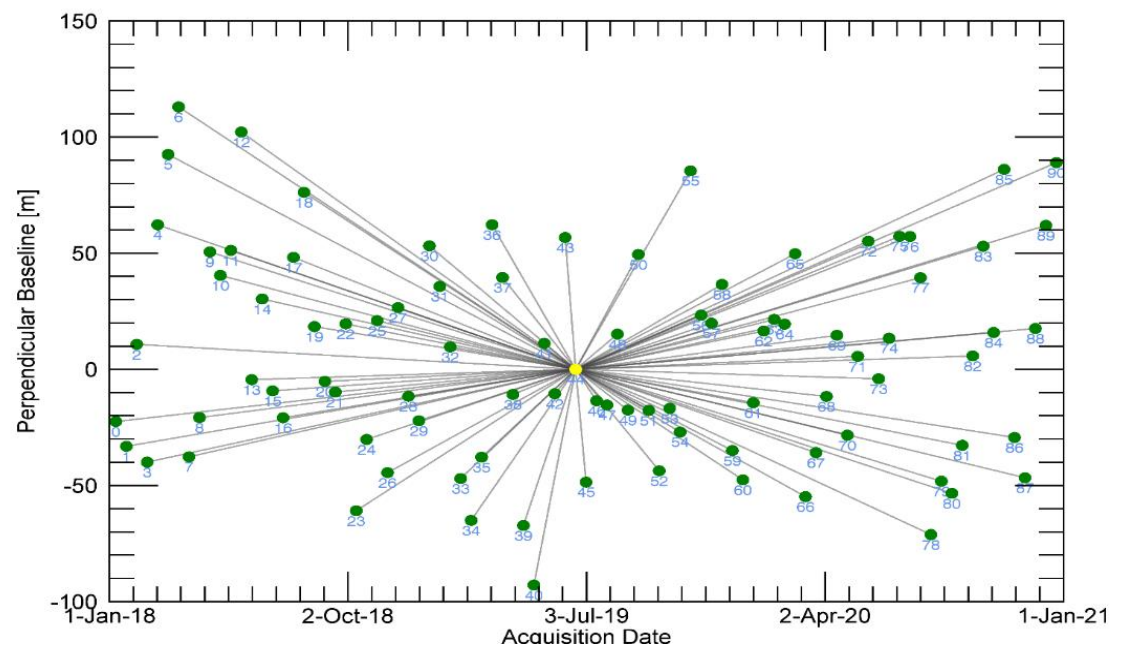

Figure 3 Perpendicular Baseline for PS-InSAR on January, $8^{\text {th }} 2018$ to December $23^{\text {rd }} 2020$

\section{LOS Velocity}

PS-InSAR can estimate the slope movement in the study area by $40.39 \%$. Based on the LOS speed map in Figure 4, massive slope movement is shown on the area of the road west of PTS now which is relatively away from the LOS direction (point A). Other than PTS, in the same year, slope movement was detected on the housing area of Jalan Selorejo (west of the UNIKA campus) which leads closer to the LOS direction (point B). But the results of this processing did not detect any slope movement on the UNIKA campus (point C) and UNTAG (point D). The average LOS Displacement (Figure 5) for PTS is $-9.85 \mathrm{~cm} /$ year, and Selorejo is 9.32 $\mathrm{cm} /$ year.

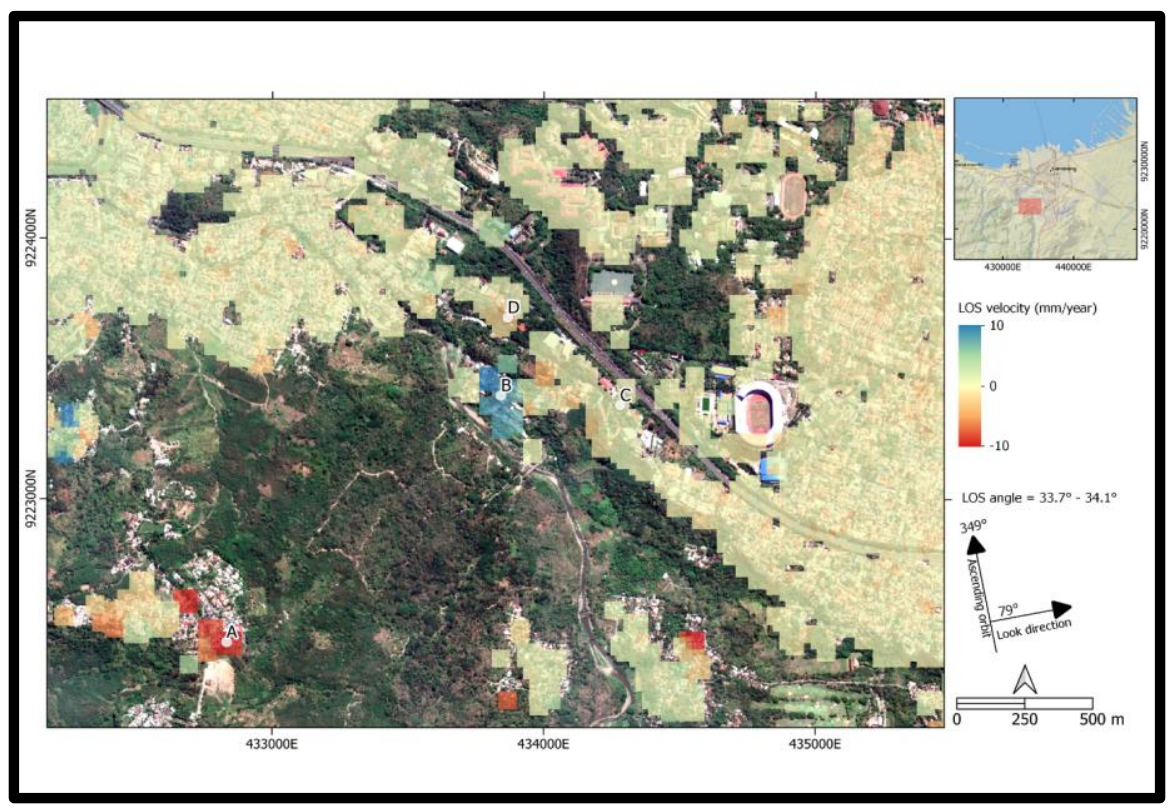

Figure 4 LOS Velocity Map PS-InSAR. PTS (A), Selorejo (B), UNIKA (C), and UNTAG (D) 


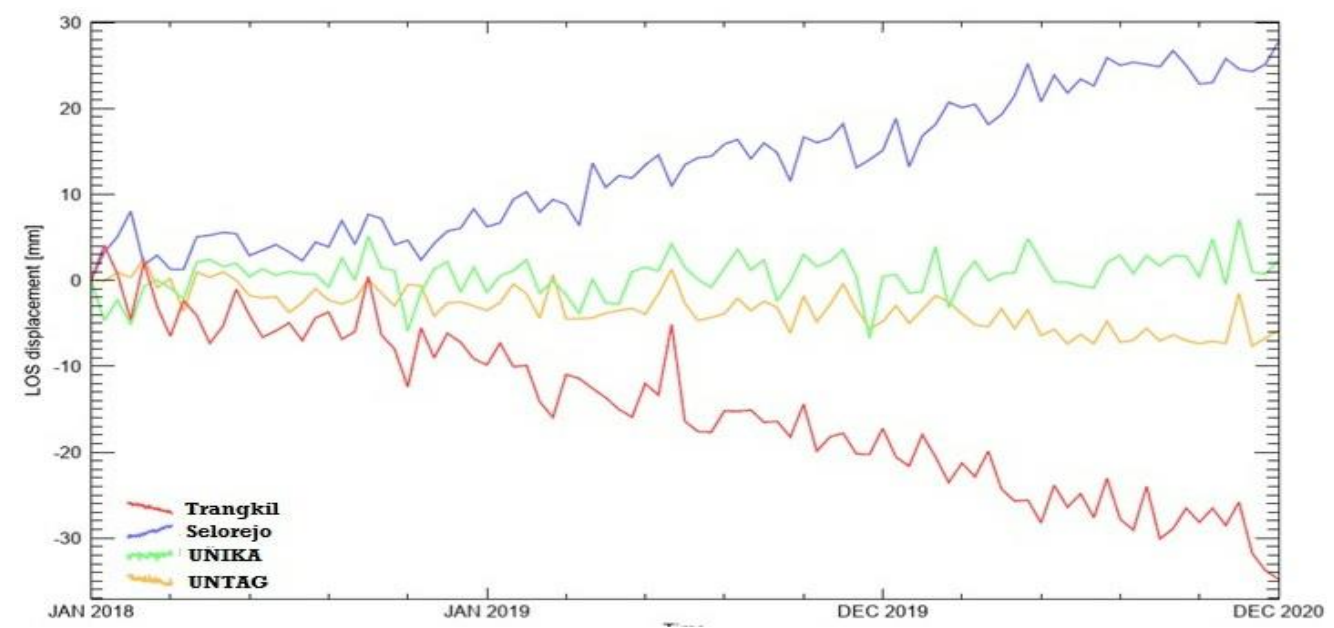

Figure 5 LOS Displacement Trangkil (red line ), Selorejo (blue line), UNIKA (green line), and UNTAG (yellow line)

Based on data from the Semarang City BPBD in 2021, heavy rain that flushed the research area on 30-31 January 2021 caused landslides in the following days, namely Trangkil Baru (Pemerintah Provinsi Jawa Tengah, 2021) and landslides in Selorejo (BPBD Semarang City, 2021). This shows that there is a relation between termites and landslides wherein the 2018-2020 range, soil movements are seen in several locations, especially in Trangkil and Housing in Selorejo-Tinjomoyo. However, the PS-InSAR method is less able to detect surface movement in areas dominated by vegetation.

\section{Creep Failure}

Field surveys were carried out with measuring moves on scarp or creep failure (Figure 6), and documentation process in the research area, including: (1) Trangkil Sejahtera Housing. From the survey results, the moves from the minor scarp which show continuity on Trangkil Sejahtera Housing with azimuth moves between N 300 (PTS 03), N 270 (PTS 04), and N 300 (PBS 01). This is thought to be related to the landslide that occurred in Trangkil Baru in 2014; (2) UNIKA and UNTAG University. Based on the LOS Map as a result of secondary data processing, the UNIKA campus and UNTAG campus did not detect any creep slope movement from 2018 to 2020, but in the end, there was some evidence of slope movement; (3) SelorejoTinjomoyo. Based on the LOS map resulting from secondary data processing, it was observed that slope movements in the Selorejo and Tinjomoyo areas, Gajahmungkur District (west of UNIKA). The survey results show the azimuth moves in these two areas range from $\mathrm{N} 135$ to $\mathrm{N} 150$.

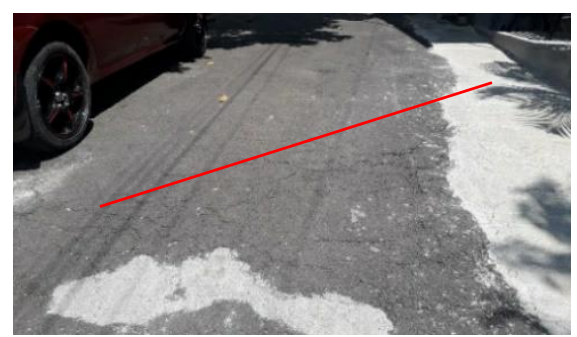

(a) Azimuth Strike: N 260; Coordinate: 0432814,9222473

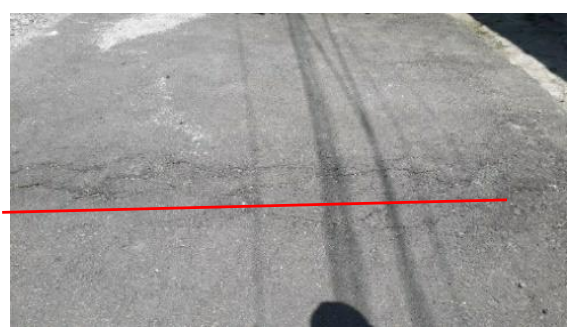

(b) Azimuth Strike: N 240; Coordinate : 0432806, 9222535 


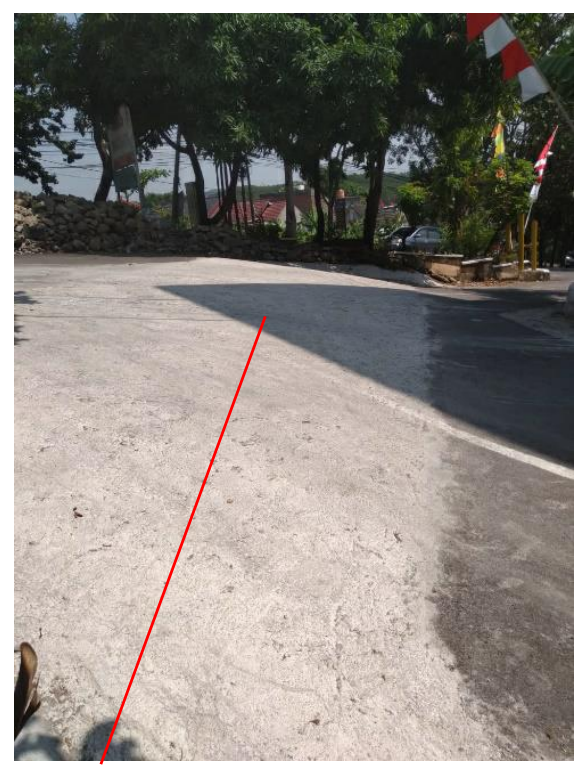

(c) Azimuth Strike: N 300

Coordinate: 432763, 9222545

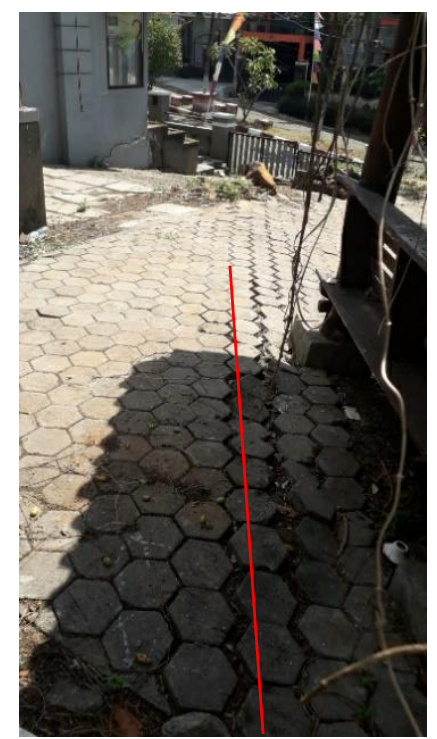

(e) Azimuth Strike: N 280

Coordinate: 0432706, 9222577

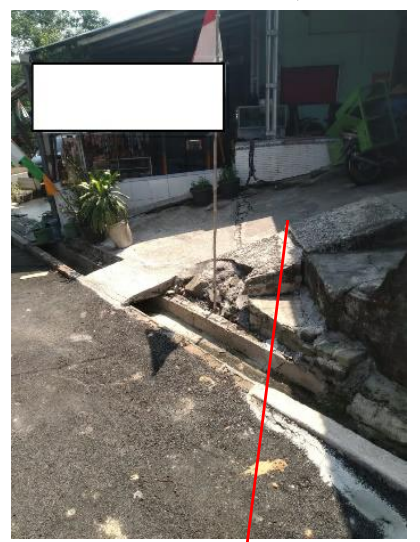

(g) Azimuth Strike: N 130

Coordinate: 433828, 9223334

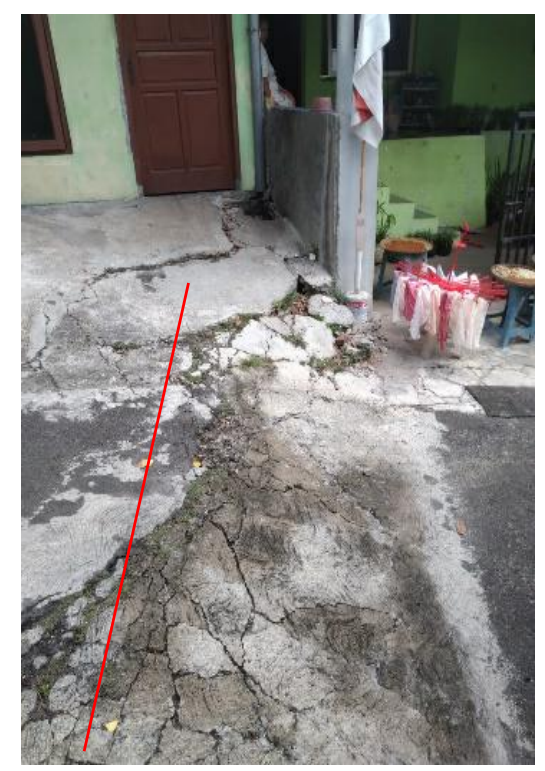

(d) Azimuth Strike: N 270

Coordinate: 432884, 9222488

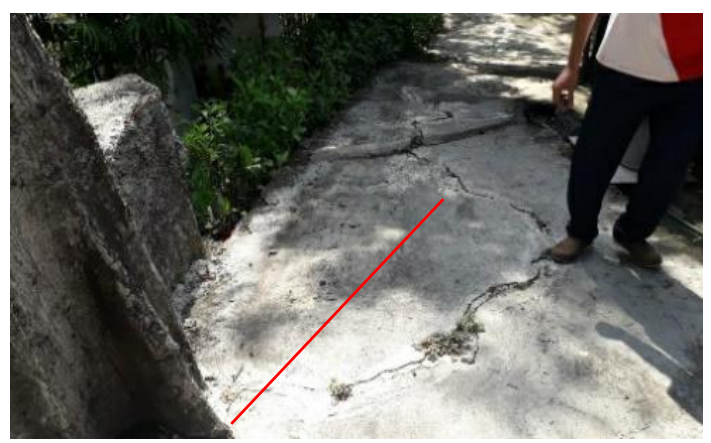

(f) Azimuth Strike: N 135

Coordinate: 433818, 9223415

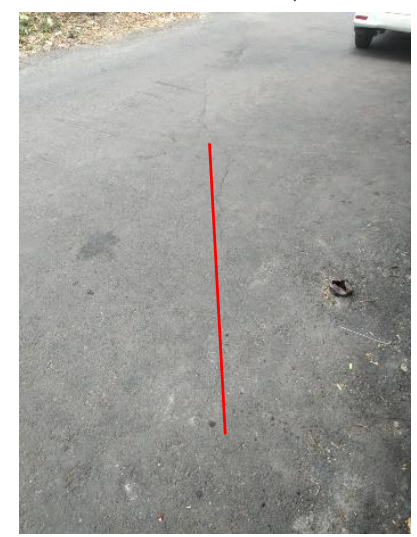

(h) Azimuth Strike: N 150

Coordinate: 434032, 9223468 


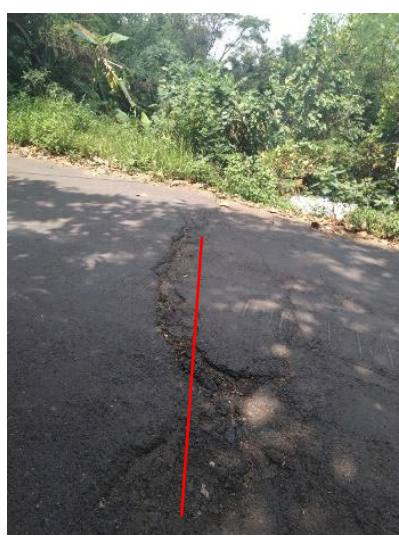

(i) Azimuth Strike: N 150

Coordinate: 433972, 9223303

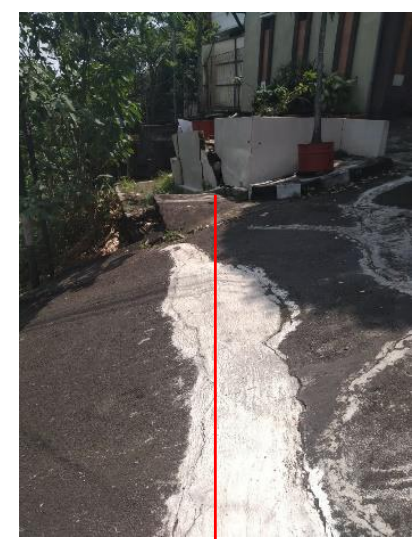

(j) Azimuth Strike: N 140

Coordinate: 433973,9223404

Figure 6 a-j Azimuth strike and creep failure moves (red line)

\section{CONCLUSION}

The results of data processing showed that the PTS and Selorejo areas detected the existence of surface movements where both areas were included in the category of prone to landslides. Landslides in 2021 near these two areas (Trangkil Baru and Selorejo) are indirectly related to very slow and invisible ground movements in 2018 to 2020. Scarp/creep failures are evidence of past movements and some are still moving constantly (Trangkil and Selorejo) and there are also areas that are not showing any significant movement (UNTAG and UNIKA). This is certainly very helpful in providing early warning by monitoring the movements in areas prone to landslides annually.

\section{ACKNOWLEDGEMENT}

High appreciation and special thanks are expressed to Dr. Suwito Eko Pramono, M.Pd., Chairman of Institute for Research and Community Service of Universitas Negeri Semarang and Dr. Moh. Sholehatul Mustofa, M.A, dean of the Faculty of Social Sciences, Universitas Negeri Semarang, who has provided funds to carry out this research.

\section{REFERENCES}

[BPBD] Badan Penanggulangan Bencana Daerah Kota Semarang. 2021. Talud Sungai Longsor Jalan Selorejo Barat IV Keluarahan Bendan Duwur, Kecamatan Gajahmungkur [Internet]. [Accessed 2021 Oct 2]. Available on: https://bpbd.semarangkota.go.id/detailpost/talud-sungai-longsor-jalan-selorejo-barat-ivkeluarahan-bendan-duwur-kecamatan-gajahmungkur.

Aslan G, Foumelis M, Raucoules D, De Michele M, Bernardie S, Cakir Z. 2020. Landslide mapping and monitoring using persistent scatterer interferometry (PSI) technique in the french alps. Remote Sens. 12(8): 1-22. doi: 10.3390/rs12081305.

Colesanti C, Ferretti A, Prati C, Rocca F. 2003. Monitoring landslides and tectonic motions with the Permanent Scatterers Technique. Eng Geol. 68(1-2): 3-14.

Ferretti A, Prati C, Rocca F. 2001. Permanent scatterers in $\{$ SAR $\}$ interferometry. IEEE Trans Geosci Remote Sens. 39(1): 8-20.

Gorazd Ž, Komac M, Jemec M. 2012. PSInSAR displacements related to soil creep and rainfall intensities in the Alpine foreland of western Slovenia. Geomorphology. 175-176: 107-114. doi: 10.1016/j.geomorph.2012.07.002. 
Hilley GE, Burgmann R, Ferretti A, Novali F, Rocca F. 2004. Dynamics of slow-moving landslides from permanent scatterer analysis. Science. 304:1952-1955.

Pemerintah Provinsi Jawa Tengah. 2021. Jenguk Korban Longsor di Gunungpati, Nawal Salurkan Bantuan Swadaya [Internet]. [Accessed 2021 Oct 2]. Available on:https://jatengprov.go.id/publik/jengukkorban-longsor-di-gunungpati-nawal-salurkan-bantuan-swadaya/.

Mantovani M, Bossi G, Marcato G, Schenato L, Tedesco G, Titti G, Pasuto A. 2019. New perspectives in landslide displacement detection using Sentinel-1 datasets. Remote Sens. 11: 21-35. doi: 10.3390/rs11182135.

Mazzanti P, Rocca A, Bozzano F, Cossu R, Floris M. 2012. Landslides Forecasting Analysis By Displacement Time Series Derived From Satellite INSAR Data: Preliminary Results.

Meisina C, Notti D, National I, Zucca F. 2013. PSI technique for analysing slow landslides : a useful tool to handle with care. International Journal of Remote Sensing. 32(24): 9521-9546. doi: 10.1007/978-3-64231325-7-10.

Naryanto HS, Prawiradisastra F, Kristijono A, Ganesha D. 2019. Penataan kawasan pasca bencana tanah longsor di Puncak Pass, Kecamatan Cipanas, Kabupaten Cianjur Tanggal 28 Maret 2018. JPSL. 9(4): 1053-1065. doi: 10.29244/jps1.9.4.1053-1065.

Paramita N, Fatturakhman ML, Maryanto S, Rijani S. 2021. Stratigrafi dan sedimentologi formasi kerek di sepanjang lintasan kalikayen, Ungaran Timur, Provinsi Jawa Tengah. J Geol dan Sumberd Miner. 22(2): 81-87. doi: 10.33332/jgsm.geologi.v22i2.580.

Ramadhan R, Widiatmaka W, Sudadi U. 2016. Pola perubahan penggunaan lahan dan evaluasi pemanfaatan ruang di Kabupaten Banjarnegara, Provinsi Jawa Tengah. JPSL. 6(2): 159-167. doi: 10.29244/jpsl.6.2.159.

Samiei-Esfahany S, Hanssen R, Thienen-Visser K, Muntendam-Bos AG. 2009. On the effect of horizontal deformation on insar subsidence estimates. Fringe 2009 Workshop. 2009 Dec; Farscaty, Italy.

Thaden RE, Sumadirdja H, Richard PW. 1975. Peta geologi lembar Magelang dan Semarang, Jawa [Internet]. [Accessed 2021 Oct 2]. Available at: https://opac.perpusnas.go.id/DetailOpac.aspx ?id=720050.

Virk A, Singh A, Mittal SK. 2018. Advanced MT-InSAR landslide monitoring: Methods and trends. J Remote Sens GIS. 7: 1-6. 